Disclosure of Interests: Uta Kiltz Consultant of: AbbVie, Biocad, Chugai, Eli Lilly, Gruenenthal, Janssen, MSD, Novartis, Pfizer, Roche, UCB, Grant/research support from: AbbVie, Biogen, Novartis, Pfizer, Jan Brandt-Juergens Consultant of: Abbvie, Affibody, BMS, Gilead, Janssen, Lilly, Medac, MSD, Novartis, Pfizer, Roche, Sanofi-Aventis, UCB, Peter Kästner Consultant of: Chugai, Novartis, Elke Riechers Consultant of: AbbVie, Chugai, Novartis, UCB, Grant/research support from: AbbVie, Chugai, Lilly, Janssen, Novartis, Pfizer, Roche, UCB, Daniel Peterlik Employee of: Novartis Pharma $\mathrm{GmbH}$, Hans-Peter Tony Consultant of: AbbVie, Astra-Zeneca, BMS, Chugai, Janssen, Lilly, MSD, Novartis, Pfizer, Roche, Sanofi.

DOI: 10.1136/annrheumdis-2021-eular.142

\section{POS1024 GUSELKUMAB PROVIDES SUSTAINED DOMAIN- SPECIFIC AND COMPREHENSIVE EFFICACY AS ASSESSED USING COMPOSITE ENDPOINTS IN PATIENTS WITH ACTIVE PSORIATIC ARTHRITIS}

L. C. Coates ${ }^{1}$, C. T. Ritchlin ${ }^{2}$, L. Gossec ${ }^{3}$, P. Helliwell ${ }^{4}$, P. Rahman ${ }^{5}$, E. C. Hsia ${ }^{6,7}$, A. Kollmeier ${ }^{8}$, X. L. Xu ${ }^{8}$, C. Karyekar ${ }^{9}$, M. Shawi ${ }^{9}$, W. Noel ${ }^{10}$, Y. Jiang ${ }^{11}$,

S. Sheng ${ }^{11}$, Y. Wang ${ }^{11}$, P. J. Mease ${ }^{12} .{ }^{1}$ University of Oxford, Nuffield Department of Orthopaedics, Rheumatology and Musculoskeletal Sciences, Oxford, United Kingdom; ${ }^{2}$ University of Rochester Medical Center, Department of Medicine, Allergy/Immunology and Rheumatology, Rochester, United States of America; ${ }^{3}$ Sorbonne Université, Rheumatology, Paris, France; ${ }^{4}$ University of Leeds, Leeds Institute of Rheumatic and Musculoskeletal Medicine, Leeds, United Kingdom; ${ }^{5}$ Memorial University of Newfoundland, Craig L Dobbin Genetics Research Centre, St. John's, Canada; ' Janssen Research \& Development, LLC Immunology, Spring House, United States of America; ${ }^{7}$ University Pennsylvania Medical Center, Rheumatology, Philadelphia, United States of America; ${ }^{8}$ Janssen Research \& Development, LLC, Immunology, La Jolla, United States of America; ${ }^{9} \mathrm{Janssen}$ Global Services, LLC, Immunology, Horsham, United States of America; ${ }^{10}$ Janssen Scientific Affairs, LLC, Immunology, Brussels, Belgium; ${ }^{11}$ Janssen Research \& Development, LLC, Biostatistics, Spring House, United States of America; ${ }^{12}$ Swedish Medical Center/Providence St. Joseph Health and University of Washington, Rheumatology Research, Seattle, United States of America

Background: Guselkumab (GUS) is a human monoclonal antibody specific to the p19-subunit of interleukin-23. GUS significantly improved signs and symptoms of PsA through Week24 (Wk24), and improvements were maintained through Wk52 in the Phase 3 DISCOVER-1 ${ }^{1}$ and DISCOVER- $2^{2}$ studies.

Objectives: Assess GUS efficacy through Wk52 in both studies utilizing composite indices.

Methods: Adult patients (pts) enrolled had active PsA despite standard therapies. Pts in DISCOVER-1 had $\geq 3$ swollen and $\geq 3$ tender joints and C-reactive protein (CRP) $\geq 0.3 \mathrm{mg} / \mathrm{dL}$; in DISCOVER-2, pts had $\geq 5$ swollen and $\geq 5$ tender joints and CRP $\geq 0.6 \mathrm{mg} / \mathrm{dL}$. $31 \%$ of DISCOVER-1 pts received $1-2$ prior tumor necrosis factor inhibitors; DISCOVER-2 pts were biologic-naïve. Pts were randomized 1:1:1 to GUS $100 \mathrm{mg}$ every 4 weeks (Q4W); GUS $100 \mathrm{mg}$ at WkO, Wk4, then every 8 weeks (Q8W); or placebo (PBO); PBO pts crossed over to GUS $100 \mathrm{mg}$ Q4W at Wk24. Composite endpoints pooled across the two studies were: Disease Activity Index for Psoriatic Arthritis (DAPSA), Psoriatic Arthritis Disease Activity Score (PASDAS), Minimal Disease Activity (MDA), and Very Low Disease Activity (VLDA). GUS vs PBO comparisons through Wk24 employed a Cochran-Mantel-Haenszel test with baseline stratification factors or Fisher's exact test; no treatment group comparisons were performed beyond Wk24. P-values were not adjusted for multiplicity. From Wk24 -Wk52, pts with missing data were considered nonresponders $(>90 \%$ of pts completed study treatment through Wk52).

Results: In randomized and treated pts from DISCOVER-1 ( $\mathrm{N}=381)$ and DISCOVER-2 ( $\mathrm{N}=739)$, pooled baseline characteristics were generally well-balanced across treatment groups and reflected active disease. Differences in response rates between GUS Q4W or Q8W and PBO were seen as early as Wk8 and increased over time through Wk24. In pts continuing GUS Q4W or Q8W, respectively, post-Wk24 response rates associated with these composite indices continued to increase through Wk52, at which time they were $54.2 \%$ and $52.5 \%$ for DAPSA LDA, $45.3 \%$ and $41.9 \%$ for PASDAS LDA, $35.9 \%$ and $30.7 \%$ for MDA, $18.2 \%$ and $17.6 \%$ for DAPSA remission, and $13.1 \%$ and $14.4 \%$ for VLDA, with no discernable difference between the GUS Q4W and Q8W dosing regimens (Table 1 and Figure 1). After PBO pts crossed over to GUS Q4W at Wk24, response rates increased through Wk52.

Conclusion: GUS $100 \mathrm{mg}$ Q4W and Q8W provided robust and sustained benefits to pts with active PsA across multiple domains, indicating that GUS may provide an alternative treatment option for the diverse manifestations of PsA.

\section{REFERENCES:}

[1] Ritchlin CR et al. RMD Open 2021; 1-11. doi: rmdopen-2020-001457

[2] Mclnnes IB, et al. Arthritis Rheumatol 2020 Oct 11. doi: 10.1002/art.41553.

Table 1. Pooled response rates for DISCOVER-1 and DISCOVER-2 randomized and treated patients.

\begin{tabular}{|c|c|c|c|}
\hline & \multicolumn{3}{|c|}{ DISCOVER-1\&2 } \\
\hline & GUS Q4W & GUS Q8W & $\begin{array}{l}\text { PBO --> } \\
\text { GUS Q4W }\end{array}$ \\
\hline $\begin{array}{l}\text { Randomized and treated patients, } n \\
\text { PASDAS }^{2} \text { LDA }\end{array}$ & 373 & 375 & 372 \\
\hline Wk 24 & $27.9 \%$ ** & $30.1 \%$ ** & $8.9 \%$ \\
\hline Wk 52 & $45.3 \%$ & $41.9 \%$ & $36.8 \%$ \\
\hline Wk 24 & $22.8 \%$ ** & $24.3 \%$ ** & $7.8 \%$ \\
\hline $\begin{array}{l}\text { Wk } 52 \\
\text { DAPSA }{ }^{4} \text { Remission }\end{array}$ & $35.9 \%$ & $30.7 \%$ & $28.2 \%$ \\
\hline Wk 24 & $10.2 \%$ ** & $8.3 \%$ ** & $2.2 \%$ \\
\hline $\begin{array}{l}\text { Wk } 52 \\
\text { VLDA }^{3}\end{array}$ & $18.2 \%$ & $17.6 \%$ & $11.0 \%$ \\
\hline Wk 24 & $6.4 \%{ }^{\star *}$ & $4.3 \%^{*}$ & $1.3 \%$ \\
\hline Wk 52 & $13.1 \%$ & $14.4 \%$ & $8.3 \%$ \\
\hline
\end{tabular}

Data reported as proportions of patients, \%. Unadjusted $p$ values at Wk24 vs PBO: ${ }^{*} p<0.05$ ${ }^{* *} \mathrm{p}<0.001$.

1 Pts randomized to PBO crossed over to GUS Q4W at Wk24.

2 PASDAS is derived from Pt global assessment of arthritis and psoriasis (0-100), Physician global assessment (0-100), swollen joint count (0-66), tender joint count (0-68), CRP (mg/L), Leeds enthesitis index score, tender dactylitis count, and the 36-item Short-Form Health Survey Physical Component Summary score. PASDAS LDA $\leq 3.2$.

${ }^{3}$ MDA is $5 / 7$ criteria met; VLDA is $7 / 7$ criteria met: tender joint count $\leq 1$, swollen joint count $\leq 1$, Psoriasis Activity and Severity Index $\leq 1$, Pt assessment of pain $\leq 15$ (0-100), Pt global assessment of disease activity $\leq 20$ (0-100), Health Assessment Questionnaire-Disability Index score $\leq 0.5$, Tender entheseal points $\leq 1$.

${ }^{4}$ DAPSA Remission: score $\leq 4$ (definition in Figure 1 legend).

Figure. Proportions of Pooled DISCOVER-1 and DISCOVER-2 Patients Achieving DAPSA LDAa Through Week 52.

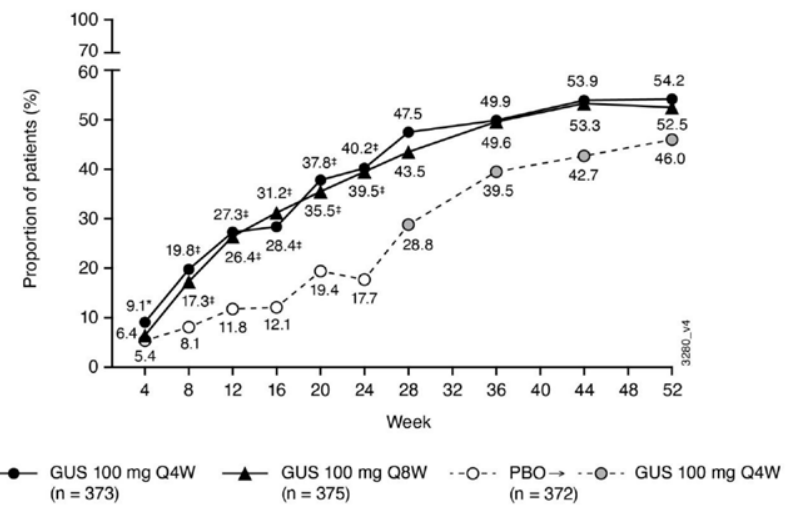

Missing data imputed as nonresponse.

. $\neq p<0.05,0.01,0.001$, respectively, vs placebo. Unadjusted (nominal) $p$ values are not controlled tor multiplicity and are

The DAPSA score is derived from tender joint count (0-68), swollen joint count (0-66). CRP (mg/dL), patient assessment of pain
$(0-10 \mathrm{~cm}$ VAS), and patient global assessment of disease activity (arthritis, $0-10 \mathrm{~cm}$ VAS). DAPSA LDA: S14. DAPSA Remission: S4.

Disclosure of Interests: Laura C Coates Consultant of: AbbVie, Amgen, Biogen, Bristol Myers Squibb, Boehringer Ingelheim, Celgene, Domain, Eli Lilly, Gilead Janssen, Medac, Novartis, Pfizer and UCB, Grant/research support from: AbbVie, Amgen, Celgene, Eli Lilly, Gilead, Novartis, Pfizer, Christopher T. Ritchlin Consultant of: Amgen, AbbVie, Eli Lilly, Gilead, Janssen, Novartis, Pfizer, and UCB, Grant/research support from: AbbVie, Amgen, and UCB, Laure Gossec Consultant of: AbbVie, Amgen, Bristol Myers Squibb, Biogen, Celgene, Eli Lilly, Gilead, Janssen, Novartis, Pfizer, Samsung Bioepis, Sanofi-Aventis, and UCB. Grant/research support from: Amgen, Eli Lilly, Galapagos, Janssen, Pfizer, Sandoz, and Sanofi, Philip Helliwell Consultant of: Galapagos, Janssen, and Novartis, Grant/research support from: AbbVie, Janssen, Pfizer, Proton Rahman Speakers bureau: AbbVie, Eli Lilly, Janssen, Novartis, Pfizer, and UCB, Consultant of: AbbVie, Amgen, Bristol Myers Squibb, Celgene, Eli Lilly, Janssen, Novartis, Pfizer, Roche, and UCB, Grant/research support from: Janssen and Novartis, 
Elizabeth C Hsia Shareholder of: Johnson \& Johnson, Employee of: Janssen Research \& Development, LLC, Alexa Kollmeier Shareholder of: Johnson \& Johnson, Employee of: Janssen Research \& Development, LLC, Xie L Xu Shareholder of: Johnson \& Johnson, Employee of: Janssen Research \& Development, LLC, Chetan Karyekar Shareholder of: Johnson \& Johnson, Employee of: Janssen Global Services, LLC, May Shawi Shareholder of: Johnson \& Johnson, Employee of: Janssen Global Services, LLC, Wim Noel Shareholder of: Johnson \& Johnson, Employee of: Janssen Scientific Affairs, LLC, Yusang Jiang Employee of: Cytel, Inc. providing statistical support (funded by Janssen), Shihong Sheng Shareholder of: Johnson \& Johnson, Employee of: Janssen Research \& Development, LLC, Yanli Wang Employee of: IQVIA providing statistical support (funded by Janssen), Philip J Mease Consultant of: AbbVie, Amgen, Boehringer Ingelheim, Bristol Myers Squibb, Eli Lilly, Galapagos, Gilead, GlaxoSmithKline, Janssen, Novartis, Pfizer, SUN, and UCB, Grant/research support from: AbbVie, Amgen, Bristol Myers Squibb, Eli Lilly, Galapagos, Gilead, Janssen, Novartis, Pfizer, SUN, and UCB.

DOI: 10.1136/annrheumdis-2021-eular.167

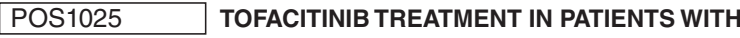 PSORIATIC ARTHRITIS AND PROBABLE DEPRESSION AND/OR ANXIETY: A POST HOC ANALYSIS OF TWO PHASE 3 CLINICAL TRIALS}

L. Gossec ${ }^{1}$, G. Citera ${ }^{2}$, A. Sellas-Fernández ${ }^{3}$, D. C. Gruben ${ }^{4}$, M. Valderrama ${ }^{5}$ S. Gómez ${ }^{5}{ }^{1}$ Sorbonne UniversitélHôpital Pitié-Salpêtrière, Paris, France; ${ }^{2}$ Instituto de Rehabilitación Psicofísica, Section of Rheumatology, Buenos Aires, Argentina; ${ }^{3}$ University Hospital Vall d'Hebron, Secció de Reumatologia, Barcelona, Spain; ${ }^{4}$ Pfizer Inc, Inflammation and Immunology, Groton, CT, United States of America; ${ }^{5}$ Pfizer Inc, Inflammation and Immunology, Madrid, Spain

Background: Depression and anxiety are highly prevalent in patients (pts) with psoriatic arthritis (PsA), ${ }^{1}$ with inflammation a key pathogenic feature of depression in these pts. ${ }^{2}$ Tofacitinib is an oral Janus kinase inhibitor for the treatment of PsA. It acts by modulating immune and inflammatory responses. The link between major depressive disorder/generalised anxiety disorder (MDD/GAD), inflammation and tofacitinib effectiveness has not been fully explored.

Objectives: Analyse the prevalence of probable MDD/GAD in pts with PsA initiating tofacitinib treatment and the impact of baseline (BL) probable MDD/GAD status on tofacitinib efficacy in these pts.

Methods: This was a post hoc analysis of data from pts who received tofacitinib 5 or $10 \mathrm{mg}$ twice daily (BID), or placebo (PBO), pooled from two Phase 3 trials (12-month OPAL Broaden [NCT01877668]; 3 6-month OPAL Beyond $[\text { NCT01882439] }]^{4}$ ). Pts with BL probable MDD and/or GAD were identified by a Short Form-36 Health Survey (SF-36) Mental Component Summary score (MCS) $\leq 38$. Pt demographics/BL characteristics and outcomes were stratified by the presence (SF-36 MCS $\leq 38$ ) or absence (SF-36 MCS $>38$ ) of BL probable MDD/GAD. At Months (M) $3 / 6 / 9 / 12$, changes from BL in SF-36 MCS were evaluated, and efficacy assessed by the proportions of pts who achieved: Psoriatic Arthritis Disease Activity Score (PASDAS) $\leq 3.2$, Health Assessment Questionnaire-Disability Index (HAQ-DI) improvement $\geq 0.35$ and Functional Assessment of Chronic Illness Therapy-Fatigue (FACIT-F) improvement $\geq 4$. BL global pain was measured via visual analogue scale.

Results: Of the 706 pts included in this analysis, BL probable MDD/GAD was identified in $46.2 \%, 44.9 \%$ and $46.2 \%$ of pts in the tofacitinib $5 \mathrm{mg} \mathrm{BID}(108 / 234)$, tofacitinib $10 \mathrm{mg}$ BID (106/236) and PBO (109/236) groups, respectively. BL disease activity was similar across the three treatment groups, independent of probable MDD/GAD status (mean PASDAS: 6.1-6.4 in pts with vs 5.8-6.1 in pts without probable MDD/GAD). In the tofacitinib $5 \mathrm{mg} B I D$ group, mean $B L$ scores for HAQ-DI (1.4 vs 1.0), FACIT-F total score (20.5 vs 32.4 ) and global pain (61.3 vs 51.5 ) indicated worse disability, fatigue and pain, respectively, for pts with vs without BL probable MDD/GAD. Similar findings were seen in the tofacitinib $10 \mathrm{mg}$ BID and PBO groups. At M3, improvements from BL in SF-36 MCS in pts with probable MDD/GAD were numerically, but not significantly, greater with tofacitinib 5 and $10 \mathrm{mg} \mathrm{BID}$ vs PBO, and these changes were largely sustained to M12 (Figure 1a). At M3, numerically greater proportions of pts achieved improvements in PASDAS, HAQ-DI and FACIT-F with tofacitinib 5 or $10 \mathrm{mg} B I D$ vs PBO, regardless of $B L$ probable MDD/GAD status (Figure 1b-d). Through M3-12, the proportions of pts who achieved PASDAS $\leq 3.2$ with tofacitinib 5 or $10 \mathrm{mg}$ BID were generally significantly greater in pts without vs with probable MDD/GAD (Figure 1b). At all timepoints, rates of improvement in HAQ-DI with tofacitinib $5 \mathrm{mg}$ BID were numerically greater in pts with vs without probable MDD/GAD, whereas the opposite was true for tofacitinib $10 \mathrm{mg}$ BID (Figure 1C). FACIT-F improvement rates with tofacitinib $10 \mathrm{mg}$ BID were consistently numerically greater in pts with vs without probable MDD/GAD, while findings were mixed for tofacitinib $5 \mathrm{mg} \mathrm{BID}$ (Figure 1d).

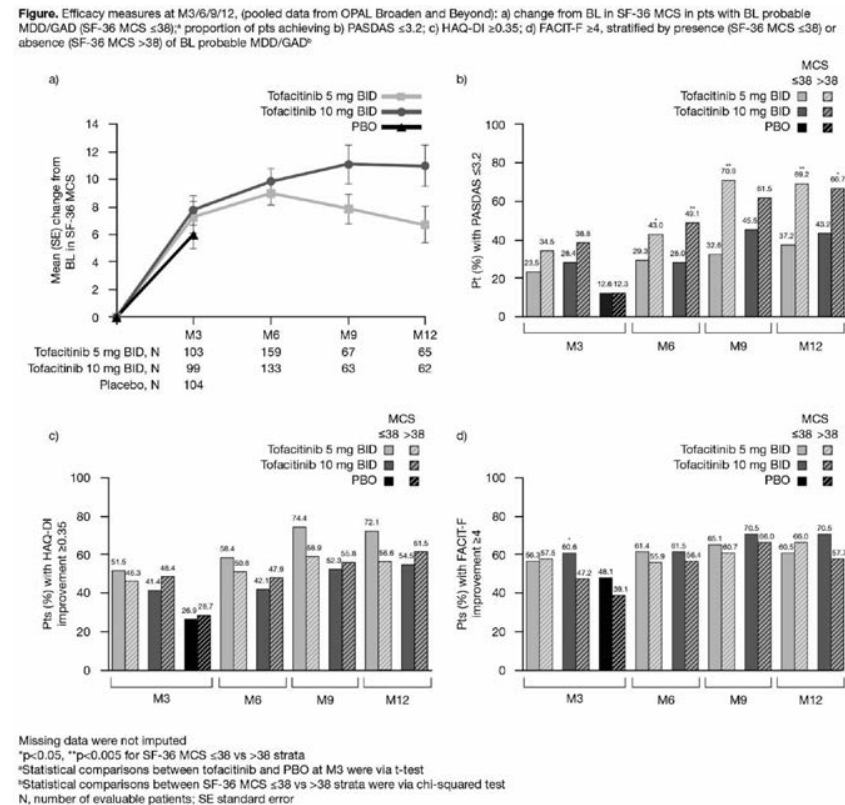

Conclusion: Around $46 \%$ of pts with PsA treated with tofacitinib had BL probable MDD/GAD (SF-36 MCS $\leq 38$ ). Pts with BL probable MDD/GAD treated with tofacitinib had sustained changes in SF-36 MCS. Rates of clinical improvement with tofacitinib were generally greater in pts without vs with probable MDD/GAD, whereas findings for disability and fatigue improvements varied between tofacitinib doses. Further research is required to evaluate the relationship between PsA and depression, to improve treatment targets and the quality of life of pts with PsA.

REFERENCES:

[1] Zhao et al. Clin Rheumatol 2020; 39: 217-225.

[2] Mathew \& Chandran. Rheumatol Ther 2020; 7: 287-300.

[3] Mease et al. N Engl J Med 2017; 377: 1537-1550.

[4] Gladman et al. N Engl J Med 2017; 377: 1525-1536.

Acknowledgements: Study sponsored by Pfizer Inc. Medical writing suppor was provided by Emma Deeks, CMC Connect, and funded by Pfizer Inc. Disclosure of Interests: Laure Gossec Grant/research support from: AbbVie Bristol-Myers Squibb, Celgene, Janssen, Eli Lilly, Novartis, Pfizer Inc, Roche, UCB, Gustavo Citera Consultant of: AbbVie, Amgen, Eli Lilly, Gema, Genzyme, Novartis, Pfizer Inc, Sanofi Genzyme, Grant/research support from: AbbVie, Amgen, Eli Lilly, Gema, Genzyme, Novartis, Pfizer Inc, Sanofi Genzyme, Agustí Sellas-Fernández: None declared, David C Gruben Shareholder of: Pfize Inc, Employee of: Pfizer Inc, Monica Valderrama Shareholder of: Pfizer Inc Employee of: Pfizer Inc, Susana Gómez Shareholder of: Pfizer Inc, Employee of: Pfizer Inc.

DOI: 10.1136/annrheumdis-2021-eular.176

\section{POS1026 GUSELKUMAB PROVIDES SUSTAINED IMPROVEMENTS IN WORK PRODUCTIVITY AND NON-WORK ACTIVITY IN PATIENTS WITH PSORIATIC ARTHRITIS: RESULTS THROUGH 1 YEAR OF A PHASE 3 TRIAL}

J. Curtis ${ }^{1}$, I. Mcinnes ${ }^{2}$, S. Peterson ${ }^{3}$, P. Agarwal ${ }^{4}$, F. Yang ${ }^{3}$, A. Kollmeier ${ }^{5}$ E. C. Hsia ${ }^{6,7}$, C. $\mathrm{Han}^{6}$, W. Tillett ${ }^{8}$, P. J. Mease ${ }^{9}$, P. Rahman ${ }^{10} .{ }^{1}$ University of Alabama at Birmingham, Department of Medicine, Immunology and Rheumatology, Birmingham, United States of America; ${ }^{2}$ University of Glasgow, Institute of Infection, Immunity \& Inflammation, Glasgow, United States of America; ${ }^{3}$ Janssen Global Services, LLC, Immunology, Horsham, United States of America; ${ }^{4}$ Janssen Research \& Development, LLC, Biostatistics, Spring House, United States of America; ${ }^{5}$ Janssen Research \& Development, LLC, Immunology, San Diego, United States of America; ${ }^{6} \mathrm{Janssen}$ Research \& Development, LLC, Immunology, Spring House, United States of America; ${ }^{7}$ University of Pennsylvania Medical Center, Rheumatology, Philadelphia, United States of America; ${ }^{8}$ Royal National Hospital for Rheumatic Diseases, Department of Pharmacy \& Pharmacology Centre for Therapeutic Innovation, Bath, United Kingdom; ${ }^{9}$ Swedish Medical Center/Providence St. Joseph Health and University of Washington School of Medicine, Rheumatology Research, Seattle, United States of America; ${ }^{10}$ Memorial University of Newfoundland, Craig L Dobbin Genetics Research Centre, St. John's, Canada 